\title{
The Victorian Critic as Naturalizing Agent
}

\author{
Jason Camlot, Concordia University
}

The keywords shared by the discourses of British nationality law and literary stylistics reveal the degree to which matters of style have been loaded with the concerns of national self-definition since the sixteenth century, at least. The OED's first cited example for usage of the verb "To Naturalize" - meaning specifically the adoption of a word or phrase into a language or into common use - comes from George Peele's The Honour of the Garter (1593), and makes an explicit analogy to the investment of a foreign immigrant with the privileges of a native born citizen. ${ }^{1}$ In this passage Peele speaks of fellow Tudor poet John Harington, who had adapted in loose translation Ariosto's Orlando Furioso into English in 1591, as one "That hath so purely naturalized/ Strange words, and made them all free denizens." ${ }^{2}$ Under the Tudors, the king acted alone to make denizens under his prerogative. ${ }^{3}$ Thus, the power over language attributed to Harington by Peele here is equivalent to the power of the King to make foreigners English subjects. The two significant Acts dealing with civic naturalization in the nineteenth century - the Aliens Act (1844) and the Naturalization Act (1870) mark the gradual move toward administrative discretion in naturalization procedure. ${ }^{4}$ Following the 1844 Aliens Act it was no longer necessary to grant letters of denization or special Acts of parliament in order for an Alien to become naturalized, ${ }^{5}$ and by the late nineteenth century, the Home Secretary had complete discretion to grant or withhold naturalization certificates "as he thought 'most conducive to the public good." ${ }^{\prime 6}$ In short, during the nineteenth century, the 
power of civic naturalization moves from a more private form of personal allegiance to a public, administrative set of procedures. It is taken out of the province of individual allegiance to a monarch into what John Stuart Mill called "the province of morality or law,", the racial (what we would now call "ethnic") identity of the English nation coming under the jurisdiction of the State which was to act in the interest of English society.

As we know from Matthew Arnold's discussion of "the State" as governing party in Culture and Anarchy, he felt it could not be relied upon as a "center of light and authority.... as a working power" because "we only conceive of the State as something equivalent to the class in occupation of the executive government, and are all afraid of that class abusing power to its own purposes. ${ }^{\prime 8}$ To avoid granting the authority over society to a specific, partisan group, on the one hand, and to avoid the dangers of anarchy, on the other, Arnold calls for the pursuit and affirmation of "our best self," for it is "[b]ut by our best self we are united, impersonal, at harmony." This idea of "the best self" is the most trustworthy locus of authority during a time of great change, the source of "right reason" that will keep the "risk of tumult and disorder," the "multitudinous processions" and "multitudinous meetings" that inevitably come with revolutionary change in check. In introducing his idea of the best self, Arnold is suggesting the cultured individual as a microcosmic equivalent to the ideal State, "or organ of our collective best self, of our national right reason."

My argument in this essay is that the stylistically endowed critic, the critic of taste and stylistic discretion described in late Victorian theories of style represents 
another version of Arnold's politically explicit "best self," another means of endowing the individual with the power to construct a desirable national character, in this case, specifically by his ability to naturalize in style the linguistically manifest, multitudinous forces of modernity. Amanda Anderson's recent argument that Arnold sought "to give critical reason an ethical dimension...by casting it as an ideal temperament or character" realized in such "key attributes" as "impartiality, tact, moderation, measure, balance, flexibility, detachment, objectivity [and] composure" ${ }^{, 10}$ stands as a most useful way to describe the motives behind much late Victorian rhetorical theory, and how it can be understood in relation to State jurisdiction over matters of culture, national identity and the sake of public benefit. The universalizing motives of the individual stylist, and the refined taste of such an aesthetic individual, work as analogues to an enlightened individual's capacity to determine what is most conducive to the public good.

Linda Dowling has noted that Arnold perceived the philological lectures of Max Müller and G.P. Marsh in the 1860s as haunting signs of the decay of a literary tradition that might successfully embody English values. As Marsh conveyed the truism that "the national history and the national language begin to be studied only in their decay," Arnold was overwhelmed with depression at the thought of where "the guardians of civilization might turn in any hopeful attempt to arrest cultural decline." ${ }^{11}$ In the second half of the nineteenth-century, prescriptive stylistics becomes an important discipline to which the guardians of civilization turn. Working from the underlying assumption of much nineteenth- 
century ethnological inquiry "that linguistic relations were evidence of racial affinity," ${ }^{12}$ and responding to models of linguistic development that conceived of linguistic change as the historical corruption of an originally pure and unified language, late Victorian principles of harmony and good taste in writing come to function as a solution to the disturbing, racially hybrid specter of language raised by philology, and to a social formation that is growing ethnically and culturally global in scope.

One of the most familiar arguments forwarded by Victorian theorists of style and rhetoric was that writing made available to the English public should work to unite all of its readers, and thus consolidate the English as a people. From this perspective — familiar to us from Wordsworth's Second "Preface" to the Lyrical Ballads (1802) - a language common to all men should be the guiding force of written communication. The idea of a common culture realized by the power of the written word was summed up neatly in 1880 by the critic T.C. Horsfall in this way:

Nothing perhaps except an invasion would do so much to bring people of different classes nearer together than they now are in England, as the possession by many persons in every class of familiar knowledge of even one great book. From it would spring the thought in common, the feeling in common, which make classes into one people. ${ }^{13}$

This fantasy of a "familiar knowledge" also informed a great variety of Victorian prescriptive essays about writing, many of them tabled with an urgency that links the establishment of guidelines for usage and form with the protection of a mode 
of communication, a method of using language that would be shared equally by all native speakers, and render critical truth universally intelligible. As in the debates surrounding the contents of the New English Dictionary, ${ }^{14}$ qualifications of English style are largely concerned with the status of foreign, and foreignrooted words, versus words of Teutonic or Anglo-Saxon origin, the main question being, what kind of balance between the two, if it be a balance at all, will allow for the achievement of a language in common, a language whose meaning is universally significant?

I identify two main positions of thought upon this question in the Victorian period, one cosmopolitan ${ }^{15}$ and individualistic in its vision, the other nationalistically insular and more socially prescriptive in its approach. The first position, characteristic of a cosmopolitan tradition of criticism and rhetoric in England (especially in the last two decades of the nineteenth-century) provides us with the image I have just mentioned of the individual critic unifying difference by a subjective absorption and technical formalization of the diverse racial content of language. The stylistic tenet of "balance" comes to imply, in this tradition — which includes such critics as Arnold, Walter Pater, George Saintsbury, Robert Louis Stevenson, John Addington Symonds and Oscar Wilde - the proper naturalization of the foreign influences that work upon the author, for the ultimate sake of expression with universal import. These theories of style are inclusive, welcoming of influences from foreign languages and the integration of passages from other writers, but also naturalizing, so that the influences are ordered by the author in such a way that they are effectively 
absorbed by the greater structure of the author's text. Pater, my focus in the final section of this essay, welcomes diverse literary influence. He asserts that "eclecticism" is a hallmark quality of his age, and a "good quality" at that, but argues further that eclecticism in itself is only an initial opportunity for modern writers. The ultimate goal of style in writing is "always to aim at the combination of as many excellences as possible."16

This idea that a writer's style must successfully combine literary influences, absorb them so that they are present but not conspicuous, would become the primary means of judging prose style in the 1880 s and 90 s. Of course, the concept of balance in style does not emerge for the first time at this point in history, but the idea of balance at this time does come to imply more specifically than it previously had the proper naturalization of language's inherent hybridity by the modern, stylistically sophisticated critic. In this regard, these late-Victorian authorities on the problem of style who discuss at length in seemingly benign terms the need for an elegant structure and symmetrical modulation in prose, with an emphasis on ordonnance and the silent assumption of phrases and sentences from earlier writers ${ }^{17}$ are also participating in a larger, nationalist and racialist debate about the proper status of foreign influences upon (or within) the English language, the English nation, and about the preferred social structure by which these two matters could best be cultivated.

For instance, Saintsbury warns against identifying style with "gaudy vocabulary," and suggests that "no competent critic will advocate a grisâtre style,"18 and yet, his solution is not to banish foreign terms, but to advocate a style 
that creates a perfect harmony between the phrases, sentences and paragraphs, establishing a perfect syntactical feudalism, so to speak, so that "[e]ach holds its own proper place and dignity while contributing duly to the dignity and place of its superior in the hierarchy." 19 Saintsbury defends the "esoteric, fastidious" and "fine" elements of language that "Briton resents" (73) in his advocacy of "harmony" as a primary quality of superior prose, and of which Pater's writing stands as the best contemporary example (according to Saintsbury). Similarly, Stevenson's statement that the "web" or "pattern" of prose-_"a web at once sensuous and logical, an elegant and pregnant texture...a compactor fitting of the parts" - defines style, and "is the foundation of art and literature," ${ }^{20}$ is implicitly about the structural naturalization of foreignness (of foreign, linguistic influence). The linguistic subtext of debates about "balance" and "organization" in prose is brought to the fore in Symonds's argument that the language with "the highest capacity for style...combines conservative respect for its native genius with plasticity, becoming by each phrase of growth a more perfect instrument of unimpeded utterance, more receptive of ideas, and more assimilative without loss of character." 21 This last point made by Symonds, that the language of style should be "assimilative without loss of character" raises the important issue of the relationship between the achievement of an objectively "harmonious" prose style, on the one hand, and the expression of the individual, on the other.

Late Victorian discussions of the modern critic as naturalizer of an increasingly complex and multifarious field of linguistic matter apply terms from the discourse of Victorian psychology (developed by the likes of Herbert Spencer, 
Alexander Bain, James Sulley, and at the end of the century, Grant Allen) to the fields of literature and aesthetics, and develop an argument about "The Aesthetics of Human Character" (the title of an 1871 article by Sulley) that approaches issues of beauty and critical truth as "the objective side of the purely pleasurable.",22 As Sulley frames it, the main question concerning "The Beautiful" is how the individual "emotional mind" can come to be "in harmony with other minds. ${ }^{, 23}$ His solution to this question arises in his figuration of an aesthetic character that acts as an agent capable of unifying and harmonizing difference. Sulley's aesthetic character is but one example of what Regenia Gagnier has identified as the emergence of a particular model for "the critic, Man of Taste, or "personality"” as "Aesthetic Man" at the Victorian fin-de-Siècle, a model characterized by its "promotion of subjectivism, individualism, consumption, and ultimately formalism."24 "For a character to be a picturesque whole," Sulley writes, "there must be a rich diversity" manifest within it, but that diversity must, in turn be harmonized by the character's attributes of "moderation" and "subtle charm.",25 "The happy mean" prevails over "extremes of excess" which consist of the "rarity of individual development" on the one hand, and the "rich diversity" of external matter, on the other. ${ }^{26}$ In similar terms, Pater tries to reconcile the categories of objectivity and individuality by asserting that a careful expression of the author's particular sense of fact will result in an "impersonal" mode of criticism. In this attempt, Pater reformulates the character of the most promising guardian of civilization from the Arnoldian "best self"-_"united, impersonal, at harmony"-into the figure of the critic as formalizing literary stylist. 
The logic behind a faith in "style" as the guardian of civilization is based upon a combination of the revelations of philology with new psychological conceptions of criticism that accommodate the fact of the critic's particular, subjective experience. This logic can best be explained by looking ahead to Oscar Wilde who had already absorbed, in his own ingenious fashion, many of the discourses and ideas that I will be sketching out in a more patient manner in this essay. In "The Critic as Artist" (1890), Gilbert explains to Ernest that "culture" is essentially the "transmission of racial experiences...made perfect by the critical spirit." ${ }^{27}$ This is so because "the imagination is the result of heredity"; it consists of the vast racial experiences implicit in the history of language. This idea of an imagination pregnant with the associations of all of the national languages that make up a thinking being, leads Gilbert to conclude that the act of "[c]riticism," which is responsible for the most fastidious use and organization of language, "will annihilate race-prejudices, by insisting upon the unity of the human mind in the variety of its forms." ${ }^{28}$ Wilde's understanding of the value of Arnold's cosmopolitan conception of critical disinterestedness, and of Pater's subjective mode of criticism may claim for critical practice a grander purpose than either Arnold or Pater would have allowed, and yet, the cue was certainly there for Wilde to take. By focusing on the critic's "individual attitude or character"29 (Arnold), and the writer's particular sense of fact (Pater), the cosmopolitan, late Victorian critic integrates the philological categories of linguistic assimilation and naturalization into his depiction of the scene of writing, and attempts to reclaim for the critic an agency over the culturally diverse scene of modernity in and 
through which he writes, much as T.S. Eliot's individual talent becomes a "finely perfected medium in which special, or very varied, feelings are at liberty to enter into new combinations" as he absorbs and refracts tradition through himself. ${ }^{30}$

The other (more insular and prescriptive) tradition of Victorian rhetoric that I have noted is characterized to varying degrees by the racial nationalism typical of what Frederic E. Faverty has dubbed Victorian "Teutomania," that is, by "the strong pro-German and anti-French" sentiment articulated in the work of many nineteenth-century philologists and historians. ${ }^{31}$ Proceeding from an assumption of the common Teutonic origin of all Englishmen, the Saxonist theory of style calls for the reversal of foreign influence upon the English language so that the common racial characteristics and national identity held in common by the English might be restored. ${ }^{32}$ Only a widespread implementation of a Saxon-based English would result in a unity of the English people, and a truly transparent means of communication between Englishmen. Rather than focus on the naturalizing agency of the culturally voracious individual critic, the Saxonist position develops a model for a "national" character that is manly and virile in its renunciation of effeminizing foreign influence, and a more explicit program for the implementation of proper English usage. This position revives the gendered terms found in seventeenth-century attacks upon the Ciceronian excesses of English Renaissance prose (resulting in the articulation of new rules for what has been called "Virile Style"33), but stresses a stronger affiliation between the foreign and the effeminate than Francis Bacon and Ben Jonson did in their promotion of English plain style. As Patricia Parker has shown, Jonson's "appeals to manliness 
and excoriations of the effeminate in style" echo the contrast of virility to effeminacy found in his Roman models, Horace and Seneca. His national model for celebrating a sinewy, muscular, hard and manly style against a "preposterous" (meaning in the period both unnatural and homosexual) effeminate deformation of style is that of a martially dominant Rome. ${ }^{34}$ In the late-nineteenth-century, by contrast, effeminacy in style is attributed to the historical corruption by Greek, Roman and Gallic influence upon a Northern, manly literature that had previously flourished in isolation from European sources. W. P. Ker's fin-de-siècle account of how the "independent strong Teutonic national powers" manifest in Epic poetry were "thwarted and interfered with" by the Romance genres of "more or less Romanised and blended nationalities" stands as a typical example of the geographic vision informing this position. ${ }^{35}$ As Lee Paterson has noted, when Ker celebrates "the hardness of the Sagas," he is simultaneously critiquing the stylistic and "sexual lability" of Oscar Wilde, and when he describes the "pernicious effect of classical studies" upon Teutonic literature, "his target is the classicist Pater."

Debates about style in the period, loaded as they are with sexual metaphors and insinuations about class identification, are especially colored by matters of national and racial influence. ${ }^{37}$ Stylistic accusations of effeminacy or rudeness generally refer, in the end, to a writer's chosen manner of handling the racial substance of language. The next two sections of my essay address the relationship between stylistics and the concerns of philology by considering how such a nationalist, linguistic protectionism prevailed upon nineteenth-century attempts to define an "English" prose style. In the context of this Anglo-centric line of style- 
theory, I then read Pater's 1888 essay, "Style," as an apotheosis of the cosmopolitan position which forwards a marked challenge to English assumptions about "common sense" communication and the inherent force of a consolidated, Saxonized discourse. Against these assumptions, and with an approach to philology's revelations of linguistic hybridism as a necessary opportunity for the individual, modern critic, these cosmopolitan critics propose - in lieu of a Saxon revival — the subjective naturalization of linguistic eclecticism.

\section{SAXON TRANSPARENCY AND PROBLEMS OF MEDIATION}

The most extreme version of the argument about writing that advocates a total exclusion of foreign influences upon the English language was made repeatedly over a period of forty years by the self-educated school-teacher, Dorset poet and philologist, William Barnes. ${ }^{38}$ From his first humble effort written to this purpose in the form of a letter to the Gentleman's Magazine in 1830 to his 1869 schoolbook entitled, Outline of English Speech-Craft, Barnes argued for the replacement of Latin and Romance rooted words with those of Germanic origin. His argument rests consistently on the idea of a language that may easily be grasped by Englishmen of all classes, for the purposes of a common understanding. In the letter of 1830 Barnes forwards this argument with the sincere hope that writers will heed it as a means of stopping the perceived corruption of contemporary letters by an influx of foreign terms. This first letter proposes a simple program by which foreign words might be replaced by an innovative use of Saxon ones, for instance, the replacement of "animalstead" for "menagerie," "mendstead" for "penitentiary," "governlore" for "political 
economy," "painlore" for "pathology," and, in reference to the science of words with which he is especially concerned, he suggests it be known as "wordlore" rather than "philology."

While Barnes clings to the basic tenets of his program throughout his career, and the employment of his innovative Saxon-equivalents in his own writing suggest his continued belief in the importance and possibility of his method, the hope that it might actually take hold and have a general impact is tempered by 1869, when he writes Speech-Craft. In this book, the English language is surveyed as a domain in which the damage has already been done, perhaps irreparably because, "English has become a more mongrel speech by the needless inbringing of words from Latin, Greek, and French, instead of words which might have been found in its older form, or in the speech of landfolk over all England, or might have been formed from its own roots and stems, as wanting words have been formed in German and other purer tongues." ${ }^{40}$ The consequence of this corruption, according to Barnes, is that English has become so very difficult to learn "in its foreign-worded fulness" and has practically become a foreign language "to unschooled men." ${ }^{41}$ Barnes's concern for a shared language easily accessible to all Englishmen is implicit in many subsequent Victorian theories of style, although the most common argument advocating a Saxon-dominated English is that it is expressively superior (because loaded with a familiar, native significance for the English speaker) and more concise.

In the philological section of Matthew Harrison's Rise, Progress, and Present Structure of the English Language (1848) — an important precursor to Herbert 
Spencer's Saxonist theory of English style - for example, Harrison initiates an argument for the greater effectiveness of a Saxon-based English style by explaining how the "monosyllabic character of the English language" ${ }^{42}$ is due to the character and environment of England's continental forefathers who were "cut off from foreign intercourse" and "conversant only with gloomy forests and stormy seas" ( $\mathrm{R}, 64)$. This resulted in the development of a language that was extremely concentrated syllabically, leading Harrison to remark that "in the name of certain things constantly before us, or in common use [basic terms for body parts, infirmities, domestic animals and the elements], the Latin language requires 146 syllables to express that, which is expressed in English by 63" (ㅈ, 67). Harrison also observes a principle of economy "in the formation of our very monosyllables themselves" ( $\underline{R}, 78)$, as words of a completely different meaning are produced by the simple change of single vowels (for example, bag, beg, big, bog [R, 79]). And further still, as a result of the comparative absence of inflexion and variation in the cases, genders and number of English nouns, foreign terms are quite easily adapted into English, enabling it "to adopt, with perfect ease, terms which do not easily amalgamate with languages of more complexity" (므, 83). This noted plasticity of English is both a blessing and a curse, according to Harrison, for while there are a number of foreign influences that have been beneficial to the development of modern English—specifically those arising from "the judicious introduction of classical terms" ( $\mathrm{R}, 90)$ which have served to temper the harsh character of the English by assimilating linguistic elements from 
the "children of softer climes and gentler aspect" $(\underline{R}, 92)$ - many of the more recent adoptions are understood to be corrupting.

In describing sources of corruption that have resulted from the introduction of foreign terms, phrases and idioms into English, Harrison begins to formulate a series of prescriptive rules for English style that are founded upon the national and racial identity of the language, and a fantasy that aligns national coherency with a shared, transparent medium of expression based upon an archaic model of usage. Opening his account of the origins of the corruption of English like a true narrative of invasion - ("In the time of Chaucer, the French language flowed in copiously upon the Anglo-Saxon" [ㅁ, 94])—-Harrison asserts that foreign terms should be allowed into English only if they indicate an object that has no English equivalent, such as the French guillotine or bayonet, or the Chinese gong ( $\underline{R}, 95)$. Outside of these instances, he says, the use of foreign words effeminizes "the manly form of our language," and the "silly pedantic affectation of interlarding our language with foreign terms" only hides the dignity of simple English "under a load of foreign frippery" $(\underline{R}, 95)$. Foreign phrases and idioms are equally deplorable to Harrison, as they are seen to "derange and interfere with the natural order of the language" ( $\underline{R}, 96)$.

Working from Harrison's assumptions about the efficacy of a "pure" English for communication, Herbert Spencer (in "The Philosophy of Style" [1852]) bases his theory of style upon "the importance of economizing the reader's or hearer's attention" and stresses the need for using Saxon words in order to achieve the greatest simplicity for his model of the reader's mind as an engine with only a 
limited amount of mental fuel to expend. Saxon words are preferred because they carry the earliest associative resonance and thus signify meaning with the least mental resistance. ${ }^{43}$ "[T] he shortness of Saxon words," he writes, "becomes a reason for their greater force," and they are more "specific," more closely linked to the concrete artifacts they signify. ${ }^{44}$ The logic that applies to vocabulary extends to grammatical structure as well. For instance, Spencer provides the example of the superiority of saying "the black horse," over "le cheval noir," and notes that the English grammatical arrangement is the more economical: "If 'a horse black' be the arrangement, then immediately on the utterance of the word 'horse' there arises, or tends to arise, in the mind an idea answering to that word; and as there has been nothing to indicate what kind of horse, any image of a horse suggests itself." ${ }^{45}$ In the English grammatical arrangement, on the other hand, the kind of horse is established before the word horse appears, thus saving unnecessary mental energy that might have been spent considering just what kind of horse was being suggested before the appearance of the adjective.

Spencer's "scientific" argument linking Saxonized English and an economy of communication had its advocates throughout the century in critics like T.H. Wright and Alfred Owen Legge. ${ }^{46}$ However, while both Wright and Legge assume that Spencer is correct in aligning Saxon with perspicuity, they each assert their own significant qualifications to the Spencerian thesis with its leveling, mechanical model of the individual mind, due to the increasing complexity of a modern culture that must take into account the discourse of science, the realities of globalization, and, as Legge puts it, the "composite nationality" of English. 
Wright's key point of departure from Spencer lies in his contestation of Spencer's idea that an economical use of Saxon English will eliminate all mediating elements of the author's personality during the process of communication. Spencer's ideal of style as a "perfectly dispassionate" algebraic expression fabricates the impossible ideal of a being "without personality." ${ }^{47}$ Contrary to this model Wright suggests that the motivation to write is based upon the author's "gradual deposit of life's experiences," and style is the "unconscious revelation of the hidden self" of the author. ${ }^{48}$ Wright's qualification introduces a real problem for a Saxonist theory of immediacy and it is this very problem of the author's "hidden self" that will be exploited by cosmopolitan critics as a locus of authorial agency when they argue that the "compromises and expedients" of language are naturalized, and rendered impersonal through the critic's discovery of his expressive self.

Equally important as a challenge to Spencer's theory of style is Legge's acknowledgment of the "composite nationality" of the English language. Up to this point, the Saxonist theories of style I have considered have mainly abhorred the reality of the English language's massive integration of foreign terms, a reality that is gradually disclosed through the century by the increased interest in comparative philology. ${ }^{49}$ This work in philology had a great effect upon how an author's style would be judged. It would allow John Addington Symonds to base a chapter about "National Style" in 1890, on the claim that it is possible "to trace the biography of a people in the development of its mother tongue, and the assimilation through speech of mental qualities derived from other races. ${ }^{150} \mathrm{It}$ 
would also be explored by Pater, in combination with Wright's point about the necessary expression of the individual in style, as a means of challenging theoretical attempts to identify a Saxon-based prose as naturally objective or transparently scientific. However, before I turn to these alternative theories of prose style, it is necessary to explain how philological models of linguistic development informed them.

\section{Philology AND Linguistic Assimilation}

In English: Past and Present (1855), Richard Chenevix Trench proposes a model of linguistic development that figures the historical moment of a foreign word's adoption as the key to its likely assimilation into English. Trench's argument states that foreign words introduced into a language "at an early period, when as yet writing is rare, and books are few or none" assimilate best and become "quite indistinguishable from natives." Once a mature literate culture has developed, however, assimilation is more difficult. In a culture with "a much written language and a full formed literature", an adopted foreign word is more likely to continue to wear "the appearance of a foreigner and stranger." Unlike Barnes's extreme position which demands that even early assimilated terms be translated back into Saxon, Trench allows for the presence of foreign-rooted terms in English; however, the allowance comes with a handy proviso, a way to distinguish between a word which has "entirely assimilated" due to its having long lived "orally on the lips of men," versus "the foreign word... which can no longer undergo a thorough transformation" in the present. ${ }^{51}$ Such distinctions would in turn be used by some critics to argue that a writer who employs 
neologisms and foreign words without discrimination corrupts pure English with unnatural foreignness.

The application of the history of language to the practice of literary criticism results in a new means of judging a writer and his character according to the kinds of words he chooses, to his 'taste' for words. As A.C. Fraser put it in his essay "Modern Style" (1857) which explores the possibilities for criticism of this new philologically-informed discipline of literary criticism: "nothing but natural taste can direct us how to select. The man who writes as he thinks will chose the Saxon element naturally, in preference to the classical, wherever it is feasible. He will chose the commonest, best known words, and his style will be stronger, broader, and strike more home." ${ }^{52}$ The writer who chooses words that do not "strike home," can subsequently be judged as one who lacks taste, or, even more seriously, he can be seen to possess a taste that is both un-English and un-manly. Such criticisms were leveled, at various points, against the writing of Carlyle and Ruskin, Arnold and Pater, and most famously at the end of the century, against Wilde.

This last kind of judgment, the hetero-Saxonist ruling that identifies the foreign effeminacies of a writer is often phrased in the binary terms of sincerity and affectation, naturalness and artificiality. We find this mode of critique in Henry Morley's account of Euphuism, which locates the origins of literary affectation in "the action upon our literature, of Italian books and manners," ${ }^{53}$ and in W. Forsyth's essay, "Literary Style" (1857), in which he warns—echoing Spenser's praise of Chaucer's linguistic purity, a phrase also cited by Arnold in 
his discussion of Chaucer ${ }^{54}$ - that authors must "not pollute the pure well of English undefiled, with the rubbish of affectation and conceit." ${ }^{55}$ This new kind of critique employs the historical paradigm of philology to support a narrative that describes a linguistic movement from natural English idiom toward an unnatural, foreign-influenced manner of expression. The presence of identifiable foreign terms in a writer's prose subsequently signals the corruption of a purer and historically anterior model. As one reviewer of the New English Dictionary expressed this assumption in 1889 , "there is no surer or more fatal sign of the decay of a language than the interpolation of barbarous terms and foreign words. ${ }^{56}$

While this defensive and accusatory use of the idea of English's "composite nationality" will be prominent in criticism through the remainder of the century ${ }^{57}$, not all accounts of this composite nationality revealed by comparative philology were negative and protectionist in attitude. As early as 1833 Edward Bulwer Lytton argued, "[e]very great literary age with us has been that in which the language has the most largely borrowed from the spirit of some foreign tongue..." ${ }^{58}$ and "every great writer of a nation a little corrupts its tongue." 59 Similarly, G.C. Swayne's 1862 essay, "Characteristics of Language," asserts that English is a great language precisely because "it is not a dainty feeder, but derives its words and phrases from all sources." ${ }^{60}$ Swayne sums up this idea with the observation that "[w]e know not how many elements of race-added to the Anglo-Saxon — may have gone to form the grand composite called Shakespeare. ${ }^{61}$ From this perspective, the composite nature of the English 
language is seen as its primary asset, and arguments for the protection against alien influence or, the re-Saxonization of English are perceived as regressive attempts to strip the language of its great expressive properties. J.A. Symonds remarks how "English is the most composite of modern languages, including as it does Teutonic, Celtic, Latin, and French elements in the body of the idiom," ${ }^{62}$ and Fitzedward Hall (in Modern English, 1873) takes great pride in the fact that "[o]ur linguistic hybridism is ineradicable," arguing that "Latin is a composite, Greek is a composite, Sanskrit is a composite. So is English; and, solely from being the completest mongrel of all, it is the most expressive of all." ${ }^{63}$

These advocates of the positive elements of English hybridism provide a gateway into my discussion of Pater's theory of style, which not only welcomes the composite nationality of English, but actually proposes a model for writing that is based upon the philological idea of linguistic naturalization. For Pater, as I will argue below, the individual stylist's difficult act of writing represents the process by which a rich linguistic hybridism and chaotic cultural inheritance is filtered through a particular subjectivity into a refined, "impersonal" critical discourse.

\section{PATER, SCHOLARSHIP AND THE NATURALIZING CRITIC}

In his essay "Style," which appeared as a kind of manifesto at the head of his collection Appreciations in 1889, Pater defies contemporary theories subscribing to the efficacious qualities of Saxon-rooted words over those that have come from "foreign" languages. Yet, his advocacy for the inclusion of foreign terms in writing is not generally explicit, but primarily assimilative. His theory of style is 
developed to allow for the inclusion of foreign influence without being overly threatening or offensive to more insular, nationalistic positions. This cautious mode of cosmopolitanism was characteristic of Pater throughout his career. ${ }^{64}$ Pater works to accomplish his veiled attack upon a hegemonic position that links literature with an insular, nationally defined morality by devising a conception of style that gives the power of "naturalization" (as he puts it) to the contemporary writer. What is targeted as foreign and effeminate by public standards of cultural salvation can be absorbed and rendered publicly tasteful again by the power of Pater's stylist. Where Trench and his followers located the proper assimilation of foreign terms in an oral past, and depicted subsequent importation as awkward and false, Pater devises a plan by which the naturalization of a foreign terminology is not subject to the historical narrative of comparative philology but is an achievable goal by the literary critic, in the present. ${ }^{65}$ Like the revolutionary writer Flavian in Marius the Epicurean (1885), the modern writer is located by Pater at a moment "in which the literary conscience has been awakened to forgotten duties towards language, towards the instrument of expression."66 The key term used by Pater to describe the process by which these duties are fulfilled and this naturalization of language accomplished is "scholarship."67

Pater defines scholarship in its broadest sense as that ability to select the best word or passage, at the exclusion of others not as fine. So, in a review of George Saintsbury's anthology, Specimens of English Prose Style, Pater remarks, "it takes a scholar indeed to make a good literary selection." ${ }^{68}$ Pater's approach to style in the writing of criticism might be described in a similar way as that of a fine 
shopper making choices based upon his "human preference" from a diverse inventory of words ${ }^{69}$ He stresses the importance of using Saxon and Latinate terms, arguing that the literary artist will allow "[r]acy Saxon monosyllables, close to us as touch and sight" to "intermix readily with those long, savoursome, Latin words, rich in 'second intention'" (으, 13). He points out the value to the prose writer of the infiltration into English of a diverse body of vocabularies, citing the recent assimilation of the phraseology of pictorial art, German metaphysics, and mystical theology, stating that "none but pedants will regret a great consequent increase of its resources" ( $\underline{S}, 12)$. Further, even the vocabulary of science is welcomed by Pater as an artistic opportunity. Johnson's dictionary (Pater's favorite) ${ }^{70}$ included the specialized scientific terms that lexicographers argued had no business in an English dictionary, and according to Pater (and the discursive contents of a piece like the "Conclusion" to the Renaissance, for instance) it is just such a specialized terminology that can contribute to an artistic rendering of the complexity of the modern mind. ${ }^{71}$ This belief leads Pater to remark that the great enterprise of the English language in the coming years "will lie in the naturalization" of this vocabulary of science $(\underline{S}, 12)$.

A version of Pater's idea for a scholarly criticism based upon refined taste of choice and arrangement was defended by advocates of new Arnoldian standards for criticism, such as John Morley. In his 1873 review of Pater's Studies in the History of the Renaissance, Morley comprehensively outlines the characteristics of this new kind of criticism in a series of oppositional terms, beginning with the topic sentence of the review which notes the slow emergence in England of a new 
"learned, vigorous" school of criticism. ${ }^{72}$ This new English criticism manages to be both learned and vigorous, to combine order and power, by fusing "German excellence of research and power of historic vision with French excellence of presentation and skill in grouping." ${ }^{73}$ Thus, Morley depicts an English criticism that is studied and forceful at the same time because it subsumes the characters of the two primary languages it is made of. ${ }^{74}$

Morley understands Pater's "fresh and inner criticism" to be exemplary of the fusion of literary power with true critical order and detachment. His account of Pater's prose style is notable for its acceptance of Pater's notorious exquisiteness as a sign of this scholarly vigor and disinterestedness. Pater skirts "[t]he peril...of effeminate and flaccid mannerism" first "by virtue of his artistic sense," and secondly "by virtue of a strain of clear, vigorous, and ordered thought, which underlies and compacts his analysis of sensuous impressions." ${ }^{75}$ It a pervading "literary conscience...scrupulosity, and...reserve" $" 76$ that apparently provides an underlying order to Pater's analysis of the diversity of human impressions, and rescues him from being dubbed, as Ruskin was at mid-century, a flaccid, hysterical sage. ${ }^{77}$ Morley is re-imagining the model of the virile stylist here as one who can shape exquisite foreignness and sensuousness into clarity and vigor by his manner of ordering and compacting his diverse source-materials. Not surprisingly, the one fault in Pater's style noted by Morley is that he quotes too much in foreign languages, for instance, French and German terms such as intimité and Heiterkeit. ${ }^{78}$ The very principle that allows for the conceptual fusion of power and reserve - the invisible linguistic absorption in English of the French 
and German characters - is seen to be contradicted by this stylistic tendency in Pater's writing. For reasons with which we are already familiar-namely, because a linguistic conception of national identity is a stake-Morley's statement of this rule is extremely harsh. As he writes: "It seems just now to be particularly the duty of the writer who respects his own language, and has the honorable aspiration of maintaining its purity, strength, and comprehensiveness, carefully to resist every temptation to introduce a single foreign word into his prose upon any pretext whatsoever." ${ }^{79}$ The foreign is good only if naturalized into invisibility by the writer.

Up to this point I have stressed the importance to Pater's definition of scholarship as the act of choosing words properly. But according to Pater, the choice of terms is only the first step in the practice of scholarship. Subsequently the terms and phrases, the "instrument for...adequate expression," must be integrated by the writer into his own work to such a degree that he can be said to "beget" a vocabulary that is "in the strictest sense original" $(\underline{\mathrm{S}}, 11)$. This second aspect of Pater's concept of scholarship attributes the agency of naturalizationan agency which philology had located in the slow historical process of linguistic development - to the writer himself. With this second process Pater answers Morley's protectionist call to duty cited above, and avoids (more often than one would think) the accusation of stylistic decadence. Paul Bourget's definition of decadent prose (translated and published in English by Havelock Ellis in 1889) describes the decadent style as "one in which the unity of the book is decomposed to give place to the independence of the page, in which the page is decomposed to 
give place to the phrase, and the phrase to give place to the independence of the word. ${ }^{, 80}$ A developed sense of what Pater means by scholarship suggests a movement in the opposite direction of such a decomposition from unified book, to page, to phrase, to independent word. It suggests, rather, a means of assimilating the independence of the word back into a new totality manifest in the unified character and vision of the individual critic.

Language is always a pre-formed material of others for Pater, the "[p]roduct of a myriad various minds and contending tongues, compact of obscure and minute association" bearing "its own abundant and often recondite laws" within it $(\underline{\mathrm{S}}, 9)$. The inherent wealth and diversity of language can be turned into a tool of precise expression by the stylist's employment of what Pater refers to at various points in his essay as "ascêsis" (, 14) or "refined usage," that is, by his ability to perform "the exclusions, or rejections, which nature demands" ( $\underline{S}, 9)$. The practice of these strategic, naturalizing rejections which results in the elimination of all "surplusage" from the translation of thought into language ("all art does but consist in the removal of surplusage" [ㅇ, 16]), constitutes the second important aspect of Pater's sense of "scholarship" ( $\underline{\mathrm{S}}, 8-10) .{ }^{81}$ Terminological eclecticism is valued by Pater only if used with what he calls "sensitive" and "fastidious scholarship" ( $\underline{\mathrm{S}}, 12,13)$, which is the recognition of the opacity of language and of its inevitable allusive quality, of "all that latent color and imagery which language as such carries in it" (ㅁ, 16-17). One must be aware of such opacity, of the ulterior significations of language, so that one can contain them, so that the unwanted resonance can be excluded and rejected. 
Pater's concept of scholarship, then, entails not only an act of tasteful selection, not simply shopping and decoration, but a scrupulous selection that serves to contain the intertextual resonance of language so that it does not interfere with the present transcription of the author's perception of the artifact he describes. As the author pursues an "absolutely sincere apprehension of what is most real to him," he realizes the singularity of the means of expression; there is, "for every lineament of the vision within, the one word, the one acceptable word" (․, 34). The writer "begets a vocabulary" by juxtaposing and arranging his chosen words so that their previous associations and unwanted significations are adapted to their immediate purpose. Only by such a fastidious "placement" of the word in the new text will the writer achieve a communication "absolutely proper to the single mental presentation or vision within" (, 27$)$. While Pater's critics sometimes would argue that he offers stylistic delicacy in lieu of real critical labor, ${ }^{82}$ Pater's own account of his conception of writing asserts that the writer's fidelity to expressing the singularity of his impression is the most laborious of all critical tasks.

The great exertion of the stylist is conveyed in Pater's discussion of the protagonist of his theory of style, Gustave Flaubert, who is dubbed "the martyr of literary style" because of his relentless, and often painful search for le mot juste, which amounted to a life-long struggle of literary labor, a "battle" against "facile" writing $(\underline{\mathrm{S}}, 24,29)$. In a brief review of the Flaubert's letters published in the Pall Mall Gazette in 1888, Pater notes the "disinterestedness" of Flaubert's service "to prose as a fine art," ${ }^{83}$ thus displacing the association of the term with Arnoldian 
detachment, and aligning it instead with the process of writing Pater advocates. ${ }^{84}$ The self-promoted lore surrounding Pater's own method of composition often parallels the account of Flaubert's fastidious work and revision he provides in "Style." As the story goes, Pater would compose on ruled paper in double-spaced sentences and gradually insert parenthetical clauses, adjectives and adverbs until an initial draft was complete. He would then copy out the whole again, still leaving each alternate line blank, and continue the process in the same manner, sometimes through numerous drafts. (Pater is supposed to have said to a contemporary, "I never publish anything until I have written it out seven times.") Edmund Gosse remarks that he had never known a writer "to whom the act of composition was such a travail and agony as it was to Pater." ${ }^{85}$ This work is defined as scholarship because it always begins in the collection of quotations, references and phrases from writers that he has researched (what Gosse called the "memoria technica" ${ }^{86}$ ), and then moves toward the complete naturalization of these materials according to the particular vision he attempts to convey, through the process of revision and integration just described.

This method of criticism is especially appropriate to an act of critical appreciation, a tendency in Pater's critical mode that led critics to accuse Pater of showing in his writing an "excess of sympathy, at the expense of the important ability to judge critically. ${ }^{87}$ The Paterian response to a criticism such as this asserts that the association of critical distance with a more sound "application of critical law" misses the universalizing potential of a criticism that is seemingly immersed in the "mere" particulars of an individual mind. Through the process of 
scholarly naturalization Pater renders the subjective idea, the writer's particular "sense of fact," universal. As Pater phrases this point: "If the style be the man, in all the colour and intensity of a veritable apprehension, it will be in a real sense 'impersonal"' (ㅌ, 35). ${ }^{88}$ Pater's model for "scholarly" composition-based upon a careful attention to vocabulary and a subsequent insertion of this vocabulary into a stylistic or syntactical structure that will contain the intertextual resonance of individual words — stands as an alternative to arguments that identify set modes of discourse with unmediated communication. It denies Spencer's association of economical, Saxon-based style with a subjectless, algebraic expression of thought. It denies the attribution of truth-value to any one designated prose style.

The correction to such simplistic conceptions of discourse comes in Pater's emphasis upon the uniqueness of the writer's sense of fact that must be conveyed with precision in language. ${ }^{89}$ As Wolfgang Iser remarks, the object can no longer function for Pater as an organizing agent. Instead, the concept of style comes to function as "a formalistic circumscription" 90 of the "chaotic variety and complexity...of the present time"(S, 38), as this complexity manifests itself in the writer's impression of the object. Such a circumscription, no longer dependent upon the object, finds its organizing principles in the formal arrangement of the words chosen to represent the writer's impression. In Pater's sympathetic criticism we often find that his most notable verbal descriptions of his perception of another artist's work are mediated by a text that has no apparent relation to the object he is describing. Iser remarks that Pater's descriptions of artifacts work from the principle that "[s]eeing is no longer perceiving, but is projecting." 91 One 
might add that it is often projecting via disparate textual sources. As Billie Andrew Inman's account of Pater's reading shows, whole paragraphs from Pater's "Conclusion" to The Renaissance, for example, seem to have been modeled directly upon passages from Hume, or else to have been translations from Fichte. ${ }^{92}$ The famous description of Leonardo's Mona Lisa, the passage that begins, "She is older than the rocks among which she sits..." ${ }^{93}$ — a passage Yeats lineated and presented as the opening poem of his Oxford Book of Modern Verse (1937) — is essentially a translation of a passage from Flaubert's La Tentation de Saint Antoine. $^{94}$

This last example represents the naturalization of a foreign influence into English in several senses. Pater's description of the painting is rather chaste compared to Flaubert's far racier description of Eunoia. Eunoia is said to have enjoyed adultery, idolatry, lies and foolishness and to have prostituted herself to all races of people. Further, Flaubert's statement that Eunoia was the mistress of thieves in Tyre, that she drank with them at night and hid assassins among the rabble (or vermin) of her warm bed, is all but absent in Pater's account, unless it is found in the idea that Mona Lisa "trafficked for strange webs with Eastern merchants." In one sense, then, the translation of Eunoia into a critical appreciation of Leonardo's Mona Lisa represents another “crafty, cheeky, slight of hand"95 as Laurel Brake puts it, by which Pater naturalizes a racy foreign source into English so that it slips under the radar of the pervading, moral institutions of censorship and public taste. In a more general sense, though, this transmutation of Flaubert's Eunoia in Pater's vision of Leonardo's Mona Lisa 
represents a basic example of Pater's idea of naturalization, and of what it means to beget an original language from linguistic material that is already loaded with ulterior expressive import, "compact of obscure and minute association" and "abundant of its own laws" (S, 9). Pater borrows the syntactical arrangement of the passage from Flaubert, as well as a few of the descriptive phrases, but alters these borrowings to serve the purpose of conveying his individual sense of $\mathrm{Da}$ Vinci's painting. Thus, the answer to the expression of his perception of one artist's painting is found in the passage of an author who is historically unrelated, but who, according his subjective mode of scholarship, is absolutely indispensable to a sincere expression of "what is most real to him" ( $\underline{\mathrm{S}}, 34)$.

To the generation that followed, texts like The Renaissance and Appreciations came to represent the kind of pure criticism that distills an entire tradition of thought and emotion into something simultaneously personal and universally perfect. Lionel Johnson conveyed this image of Pater's criticism in his 1894 essay, "The Work of Walter Pater": "There is a strange purity of effect, the result of a refiner's fire, through which it has passed...In the finer portions of Mr. Pater's work, there is a 'whiteness,' a 'candour,' indescribably felt, through this purity and cleanliness of it, as though there were a 'sort of moral purity' in art of so scrupulous and dainty a distinction." ${ }^{96}$ Johnson's comment upon the effect of Pater's prose cautiously locates the moral element of literature in the scrupulousness of Pater's style, remarking (as Amanda Anderson puts it) how "Pater elevates stance itself as a value. ${ }^{.97}$ It is as though the whole range of debate concerning the national status of the English language, the diverse racial histories 
it contains, and the implications of such linguistic hybridity for the definition of the modern English subject has become refracted by Pater's stylistic measure into the "whiteness" and "cleanliness" of his prose. The inherent diversity of language is still present but as a result of Pater's "strange purity of effect," it now is only "indescribably felt," because it has been formally resolved, cleaned away.

As I noted at the beginning of this essay, Oscar Wilde was, for a time, equally optimistic about the integrating and harmonizing potential of such a cosmopolitan, Paterian mode of criticism. As he wrote in his 1890 review of Appreciations: "The legacies of heredity may make us alter our views of moral responsibility, but they cannot but intensify our sense of the value of Criticism; for the true critic is he who bears within himself the dreams and ideas and feelings of myriad generations, and to whom no form of thought is alien, no emotional impulse obscure. ${ }^{198}$ Wilde's insistence upon the truth of his critical definitions of such key terms such as "immoral," "unintelligible," "exotic," "unhealthy," in opposition to their "misuse" which he attributes to "the natural inability of a community corrupted by authority [read, the mass press] to understand or appreciate Individualism" represents an adaptation for a mass cultural sphere of the agency over one's begotten vocabulary that Pater attributed to the aesthetic critic. ${ }^{99}$ Without Pater's concepts of language and craft, the identity of the prose writer becomes in much late-century discourse, the fetishized manifestation of personality or "soul" in style. Wrenched from the context of language as a medium of communication, this fascination with the personality of the author was promoted both by the emerging sciences of aesthetic psychology and quantifying 
stylistics, and by the tactics of the New Journalism. ${ }^{100}$ In the former case, psychological and quantitative theories of style proposed methods by which the personalities of authors could be scientifically calculated and graphed as data. In latter case, the popular press sold a facile idea of authorial uniqueness without positing a developed theory of expression. The concept of style as a verbal index of individual character dominates essays on rhetoric at the very end of the century.

Wilde performed his own refraction of Pater's theory of style, but without forcing a split that many of his contemporaries promoted between the individual on the one hand, and the racial resonance implicit in all language, on the other. Because the individual critic becomes the refracting medium of all previously "alien" thought and emotion, the means by which the "myriad generations" inherent in the history of language are to be absorbed and coherently communicated, the concept of the individual stylist or artist becomes increasingly important for Wilde's own "sense of the value of Criticism." Arnold and Pater articulated what the literary critic could hope to accomplish in the discursively complex modern age. It was up to an heir like Oscar Wilde to try and implement the theory, in an attempt to preserve some sense of critical and artistic authority over the idea of an English, or Western culture, at the dawn of a new, global, mass culture. 
1 “naturalize, v." I.2.b. Oxford English Dictionary. Ed. John Simpson. 3rd. ed. OED Online. Draft June 2003. Oxford University Press. 4 Jul. 2003. <http://0dictionary.oed.com.mercury. concordia.ca:80/cgi/entry/00321559>

${ }^{2}$ George Peele, The Works of George Peele, 2 vols., ed. A.H. Bullen (London: John C. Nimmo, 1888), 2:318.

${ }^{3}$ J. Mervyn Jones, British Nationality Law and Practice (Oxford: Oxford UP, 1947), 39; Ann Dummett and Andrew Nicol, Subjects, Citizens, Aliens and Others: Nationality and Immigration Law (London: Weidenfeld and Nicolson, 1990), 29. John Cutler, The Law of Naturalization as Amended by the Naturalization Acts, 1870 (London: Butterworths, 1871), 5-6. The other way to become naturalized was by a special Act of parliament, but still with the basic understanding of citizenship to mean personal allegiance to the monarch. As Dummett and Nicol remark, it was only in 1886 that the court determined (in Isaacson v. Durant) that allegiance was to the Crown, not the person of the monarch, and still, even then, "although the monarch in a politic capacity, not the monarch in person, was held to be the object of allegiance in law, the doctrine of personal allegiance to the monarch remained of prime political importance throughout the first half of the twentieth century" (Dummet and Nicol, 91).

${ }^{4}$ Dummett and Nicol, 85 .

${ }^{5}$ Jones, 74-77.

${ }^{6}$ Dummett and Nicol, 85; Jones, 77. For a more detailed account of the various sections of the 1844 Aliens Act and 1870 Naturalization Act, see Jones 74-107. 
${ }^{7}$ John Stuart Mill, On Liberty [1859] (New York: Penguin books, 1985), 149.

${ }^{8}$ Matthew Arnold, Culture and Anarchy [1869] (New York: The Macmillan Company, 1931), 92.

${ }^{9}$ Arnold, Culture and Anarchy , 92-93, 94, 95.

${ }^{10}$ Amanda Anderson, The Powers of Distance: Cosmopolitanism and the cultivation of Detachment (Princeton and Oxford: Princeton UP, 2001), 115.

${ }^{11}$ Linda Dowling, Language and Decadence in the Victorian Fin de Siècle (Princeton, New Jersey: Princeton University Press, 1986), 108-9.

${ }^{12}$ George W. Stocking, Jr., Victorian Anthropology (New York: Free Press, 1987), 57-58.

${ }^{13}$ T.C. Horsfall, "Painting and Popular Culture." Fraser's Magazine n.s. 21(1880): $855-56$.

${ }^{14}$ On the wings of this faith in the nationalizing force of language, Richard Chenevix Trench properly initiated the modern debate about what a dictionary of the English language should be in his long critical essay, On Some Deficiencies in Our English Dictionaries (London: W. Parker and Son, 1860), first published in 1857 in the Transactions of the Philological Society. Trench's essay, and J.H. Mardsen's 1859 critique of Trench, "Dr. Trench on English Dictionaries." Edinburgh Review 109 (1859): 365-386, both reveal how close the language of a concern with the compilation of a national dictionary can be to the language of immigration policy. While I will not pursue a consideration of the racial and nationalist assumptions implicit in English dictionary projects to the end of the 
century, it is important to note that much of the defensive zeal found in Trench's and Mardsen's visions of the dictionary carried over into debates about the compilation of the early volumes of the New English Dictionary (what would become the Oxford English Dictionary) albeit under the guise of greater professionalism and scientific principle. John Willinsky's study of the OED is useful for its focus on the dictionary as the creator of a literary canon, or as he puts it, "the construction of a usable past" (Empire of Words: The Reign of the OED [Princeton, New Jersey: Princeton University Press, 1994], 5). Linda Dowling's thesis that the inclusive source-policy initiated under James Murray's editorship suggested "the darker possibility of cultural decline" (Dowling, 98-9), while not completely accurate- because the OED may just as easily be read as historical chronicle of English ascendancy in language - is still representative of one influential ideal of the dictionary as a conservative representation of Englishness.

${ }^{15}$ I use this term with Amanda Anderson's examination of its historical significance in mind to mean both an openness to the influence of diverse forms of culture, expression, and thought, and, most importantly, as "the expression of the need above all to enact or embody universalism, to transform it into a characterological achievement" (Anderson, 31).

${ }^{16}$ Walter Pater, "English Literature" [1886]. Essays from 'The Guardian' (London: Macmillan and Co., 1910), 15.

${ }^{17}$ See Dowling, 190. 
${ }^{18}$ George Saintsbury, "English Prose Style," [1885] The Collected Essay and Papers of George Saintsbury, 1875-1920, 4 vols. (London and Toronto: J.M. Dent \& Sons Ltd., 1923), 3:117.

${ }^{19}$ Saintsbury, "Modern English Prose," [1876] The Collected Essay and Papers of George Saintsbury, 1875-1920, 4 vols., 3:83.

${ }^{20}$ Robert Louis Stevenson, "On Style in Literature: Its technical Elements," Contemporary Review (1885): 551-3

${ }^{21}$ John Addington Symonds, Essays Speculative and Suggestive [1890] (London: Smith, Elder, \& Co., 1907), 176.

${ }^{22}$ James Sulley, “The Aesthetics of Human Character," Fortnightly Review 9 (1871): 505. For a discussion of Pater's use of key terms from Victorian psychology see, Ian Small, “The Vocabulary of Pater's Criticism and the Psychology of Aesthetics," British Journal of Aesthetics 18 (1978): 81-87. ${ }^{23}$ Sulley, 505 .

${ }^{24}$ Regenia Gagnier, The Insatiability of Human Wants: Economics and Aesthetics in Market Society (Chicago and London: U Chicago P, 2000), 91, 54. Gagnier's study traces the convergence of the late Victorian disciplines of aesthetics and economics (embodied by figures like Pater and economist Stanley Jevons) in their promotion of subjectivist and formalist approaches to their respective fields.

${ }^{25}$ Sulley, 519, 520 .

${ }^{26}$ Sulley, 530 . 
${ }^{27}$ Oscar Wilde, "The Critic as Artist," [1891] The Artist as Critic: Critical Writings of Oscar Wilde. Ed. Richard Ellman. (Chicago: U of Chicago P, 1982), 384.

${ }^{28}$ Wilde, "Critic as Artist," 405.

${ }^{29}$ Anderson, 112.

${ }^{30}$ T.S. Eliot, "Tradition and the Individual Talent," TheNorton Anthology of

English Literature, $6^{\text {th }}$ ed., ed. Abrams et al. (New York: Norton, 1993), 2:2173. Michael Tratner's account of Eliot's idea of “cultural disintegration" proves nineteenth-century stylistic theory to be a significant prototype for modernist notions concerning how to unify the increasingly culturally diverse and divided strata of society. As Tratner writes: "Eliot had left the United States...to escape a culture that seemed to him undergoing irreparable disintegration as a result of mixed immigration...Eliot's prime goal was to have the cultural activities of the upper group [i.e. the cultural elite] become forces for unifying the strata." (Michael Tratner, Modernism and Mass Politics [Stanford, CA: Stanford UP, 1995], 167-168.)

${ }^{31}$ Frederic E. Faverty, Matthew Arnold The Ethnologist (New York: AMS, 1968), 13.

${ }^{32}$ For Stocking, Jr.'s discussion of Anglo-Saxon racialism, and how it worked to define English national identity at mid-century, see Stocking, Jr., 62-69. 
${ }^{33}$ See Patricia Parker, "Virile Style,” Premodern Sexualities. eds. Louise Fradenburg and Carla Freccero (New York and London: Routledge, 1996), 201222.

${ }^{34}$ Parker, 207-208.

${ }^{35}$ W.P. Ker, Epic and Romance [1896] (New York: Dover, 1956), 49.

${ }^{36}$ Lee Paterson, "The Heroic Laconic Style: Reticence and Meaning from Beowulf to the Edwardians," Medieval Literature and Historical Inquiry: Essays in Honor of Derek Pearsall. ed. David Aers (Rochester, New York: Brewer, 2000), 155.

${ }^{37}$ The terms race and nation are used here with the more flexible meanings they held in the nineteenth century to indicate points of cultural affinity between groups of people established "on the basis of similarities of physical type, religion, political institutions, customs, and above all, language" (Stocking, Jr., 51).

${ }^{38}$ See Richard W. Bailey, Images of English: A Cultural History of the Language (Ann Arbor: The U of Michigan P, 1991), 192-3

${ }^{39}$ William Barnes ['Dillettante'], "Corruptions of the English Language." Gentleman's Magazine 100 (1830): 503.

${ }^{40}$ William Barnes, An Outline of English Speech-Craft [1869] (London: C.K.

Paul, 1878), 101. Also cited in Bailey, 194

${ }^{41}$ Barnes, Outline, 101. 
${ }^{42}$ Matthew Harrison, The Rise, Progress, and Present Structure of the English Language (London: Longman, Brown, Green and Longman's, 1848), 65, hereafter abbreviated $\underline{R}$ and cited parenthetically by page number in my essay. Significantly, by 1850, arguments counter to Harrison's isolationist vision of English purity were being developed and voiced at the meetings of the Philological Society of London (founded in 1842). For example, in his paper "On the Probable Future Position of the English Language" (delivered February 22, 1850), Thomas Watts presented a vision of English not as a pure, foundational language, but rather, as "essentially a medium language" which unites "as no other language unites, the Romanic and the Teutonic stocks," and which would thus likely make English the most widely used language on earth. Cited in Hans Aarsleff, The Study of Language in England, 1780-1860 (Minneapolis and London: U of Minnesota P, 1983), 222. For Aarsleff's account of the Philological Society of London and the origins of the OED project, see Study of Language, 211-263.

${ }^{43}$ Herbert Spencer, "The Philosophy of Style," [1852] Literary Style and Music (New York: Philosophical Library, 1951), 2-3, 4. In opposition to Spencer's belief of the effect of these early associations with Anglo-Saxon words, George Henry Lewes argues in his The Principles of Success in Literature (1865) that "their very homeliness excludes them from certain places where their power of suggestion is a disturbance of the general effect." On most other matters, Lewes is in agreement with Spencer's approach. George Henry Lewes, The Principles of Success in 
Literature [1865] (New York and Melbourne: Walter Scott Publishing Co., 1942), $134-5$.

${ }^{44}$ Spencer, 6-7.

${ }^{45}$ Spencer, 9 .

${ }^{46}$ T.H. Wright's essay "Style," is essentially a summary of Spencer's theory, in which Wright underscores the point that "the canon which prefers words of Saxon to words of Latin origin is justified."(T.H. Wright, "Style," Macmillan's Magazine 37 [1877]: 78-9.) Similarly, Alfred Owen Legge's essay "Concerning Style," cites Spencer's thesis of the economy of mental power, and ultimately agrees with the idea that Saxon-rooted words best achieve these goals of style, in spite of the parallel observation that the principles outlined by Spencer are less and less observed by modern writers. (Alfred Owen Legge, "Concerning Style," Manchester Quarterly 2 [1883]: 42-3.)

${ }^{47}$ Wright, 81.

${ }^{48}$ Wright, 84.

${ }^{49}$ For the problem of foreign influence upon the English language, see H. Marmaduke Hewitt's A Manual of Our Mother Tongue (London: Joseph Hughes, 1887). The third part of Hewitt's book attempts a history of the English language in order to answer the question, "What is the Proportion of Foreign words in English?" Hewitt, 319.

${ }^{50}$ Symonds, 175. 
${ }^{51}$ Trench, English: Past and Present (London: John W. Parker and Son, 1855), $12-$ 13.

${ }^{52}$ A.C. Fraser, "Modern Style," North British Review. 26 (1857): 187.

${ }^{53}$ Henry Morley, "Euphuism," Quarterly Review 109 (1861): 354.

${ }^{54}$ This was said by Spenser in The Faerie Queene IV, ii, stanza 32, and is cited by Arnold in "The Study of Poetry," [1880/1888] Four Essays on Life and Letters, ed. E.K. Brown (New York: Appleton-Century-Crofts, 1947), 77.

${ }^{55}$ W. Forsyth, "Literary Style," Fraser's Magazine 55 (1857): 437.

${ }^{56}$ Henry Reeve, "The Literature and Language of the Age," Edinburgh Review 169 (1889): 348.

${ }^{57}$ See especially Charles Mackay's "English Slang and French Argot" in which Mackay finds the English language in a state of decay due to the recent infiltration into the modern usage of "the imperfectly educated vulgar of the middle and upper classes" a "cant," or slang, that has its origins in the Gaelic and Kymeric rooted language of the Irish laborers who emigrated to England before the Reign of Queen Elizabeth, on the one hand, and the language "used by the gypsy hordes that first commenced to invade the British Isles...in the fifteenth century," on the other. While, according to Trench's model, these linguistic influences should have been well assimilated because of their early encounter with the English language, Mackay's essay suggests that the historical argument of corruption can look far backwards as well as to the recent past for its sources, but will always have immediate relevance as regards the class and taste of the language user in the 
present. ("English Slang and French Argot: Fashionable and Unfashionable." Blackwood's Edinburgh Magazine 143 [1888]: 690-704.)

${ }^{58}$ Edward Bulwer-Lytton, England and The English [1833] (London: George Routledge and Sons, 1874), 261.

${ }^{59}$ Bulwer-Lytton, 262.

${ }^{60}$ G.C. Swayne, "Characteristics of Language," Blackwood's Edinburgh Magazine 91 (1862): 368.

${ }^{61}$ Swayne, 374.

${ }^{62}$ Symonds, 206.

${ }^{63}$ Fitzedward Hall, Modern English (New York: Scribner, Armstrong and Company, 1873), 327. Also cited in Bailey 195.

${ }^{64}$ The desire not to offend his readers was a general concern of Pater's at this time. Laurel Brake remarks how Pater was extremely cautious in choosing for inclusion in Appreciations only those essays that he was sure would not be received as controversial, as the "Conclusion" to the Renaissance had been. The one essay in Appreciations that did provoke extreme criticism, "Aesthetic Poetry," was withdrawn from the 1890 edition. As Brake sums up Pater' position among the prominent critics during this period: "If Oscar Wilde at this time sought to be provocative, exploiting the spectrum of latitude in the press, and Arnold was also, even as an elder critic, willing to reprint the [controversial] Shelley and Tolstoy reviews, Pater emerges in his criticism of the period as the most sensitive to the prevailing morality of the readers of his books, most anxious to construct a 
reputation of rectitude to survive him" (Laurel Brake, Subjugated Knowledges: Journalism, Gender and Literature in the Nineteenth Century [New York: New York University Press, 1994], 73-74). Elsewhere Brake argues that the meaning of Pater's particular advocacy of style "may be enlarged to comprise not only formalist ends which establish the autonomy of art from culture" but may be understood further "as an intervention in the literary politics of the day which allies itself with an alternative culture to the hegemonic culture. (Brake, "Aesthetics in the Affray: Pater's Appreciations, with an Essay on Style," The Politics of Pleasure: Aesthetics and Cultural Theory. ed. Stephan Regan. [Buckingham: Open UP, 1992], 67.)

${ }^{65}$ Pater's theory of style can also be understood as an answer to Müller's idea that linguistic disease originates in the historical process by which metaphorical language becomes unhinged from its original meaning. Müller argued that when a word "first used metaphorically, is used without a clear conception of the steps that lead from its original to its metaphorical meaning...we have diseased language" (cited in Stocking, Jr., 60). As Pater's stylist "begets a vocabulary" en route to accurately expressing his "sense of fact" he, arguably, revitalizes language's status as a concretely grounded system of signification.

${ }^{66}$ Pater, Marius the Epicurean: His Sensations and Ideas, 2 vols. [1885]. (London: Macmillan and Co., Limited, 1910), 1:97.

${ }^{67}$ Dowling discusses Marius the Epicurean in terms of Pater's "familiarity with the contemporary revolution in philological science, and the complex linguistic 
reality that that science had taken as its object of inquiry" (Dowling, 117). While she stresses Pater's attempts to integrate elements of Latin syntax into his English prose, I will stress Pater's motive of naturalizing a more disparate range of foreign linguistic elements. For Dowling's discussion of Pater see 110-140.

${ }^{68}$ Pater, "English Literature," 3-4. The very word "scholarship" carried an important resonance of its own at the time Pater was employing it in this rather specific manner. Ian Small argues that Pater's critical writings emerged in opposition to the more "scholarly" works that the English academic establishment began to produce in the 1880s (Ian Small, Conditions for Criticism: Authority, Knowledge, and Literature in the Late Nineteenth Century [Oxford: Oxford UP, 1991], 1-30). As Small remarks, "most reviewers, when they discussed Pater's scholarship, noted his ignorance of contemporary research" (Small, Conditions, 105). But Pater's "ignorance," or rather his refusal of a definition of scholarship that is based upon standards of evidence and guidelines for citation is challenged by his own personal definition of that term, which, from its earliest conception was articulated not as the proper performance of an institutionally sanctioned activity, but as an internal process of self-culture.

Pater's earliest formulation of the relationship between the writer and the scholar may have appeared in a paper he delivered in 1864 to the Old Mortality Society on Fichte's "Ideal Student". According to Billie Andrew Inman in Walter Pater's Reading: A Bibliography of His Library Borrowings and Literary References, 1858-1873 (New York \& London: Garland Publishing, Inc., 1981), 
68-72, Pater read Fichte's Concerning the Scholar's Vocation, which stresses the idea of self-culture, that is, the cultivation of the scholar's "sensibility" for the purpose of achieving his "ultimate and supreme goal" which is "complete harmony with himself and--so that he can be in harmony with himself--the harmony of all external things with his own necessary, practical concepts of them" (Johann Gottlieb Fichte, Fichte: Early Philosophical Writings, trans. and ed. Daniel Breazeale [Ithaca and London: Cornell University Press, 1988], 150). Fichte explains this process as the scholar's progress towards becoming an artist. ${ }^{69}$ Pater, "Style," [1888] Appreciations, with An Essay on Style (New York: The Macmillan Company, 1906), 7, henceforth abbreviated $\underline{\mathrm{S}}$ and cited by page number in parentheses in my essay. Gagnier notes this connection between Pater's model for the aesthetic critic and the Jevonsonian model of man in consumer society: "Just as economic man chooses between scarce commodities, so aesthetic man discriminates between pleasure" (Gagnier, 55).

${ }^{70}$ As Pater writes: "Any writer worth translating at all has winnowed and searched through his vocabulary, is conscious of the words he would select in systematic reading of a dictionary, and still more of the words he would reject were the dictionary other than Johnson's..." $(\underline{S}, 11)$. Pater's advocacy of Johnson's dictionary over more recent ones may be due to its notable inclusiveness both of foreign-rooted terms and of technical words from the sciences.

${ }^{71}$ Both Mardsen and Trench are against the inclusion in their dictionaries of neologisms and the nomenclature of science. These words Mardsen calls "un- 
English," and he familiarly cites Johnson as the negative example, remarking that "[t]here is scarcely a page in Johnson which does not contain some word that has no business there [because it is a scientific term]" (Mardsen, 380).

${ }^{72}$ John Morley, "Mr. Pater's Essays," Fortnightly Review n.s. 13 (1873): 469.

${ }^{73}$ Morley, “Mr. Pater's,” 470.

${ }^{74}$ A historical version of this argument was forwarded in more explicitly nationalistic, philology essays, where claims for the predominance of the English language in the future were based upon the idea that English had assimilated the best of other languages into itself and had thus ascended to the status of a universal medium of expression. Two notable examples of this argument from the period are William Axon's, English: The Dominant Language of the Future (1889), and A. Melville Bell's, "The Claims of the English Language to Universality" (1888). But here, Morley is applying this historical assertion as a new category of modern criticism, one that "disengage[s] itself from the futile hubbub" of earlier, more strictly provincial, English criticism. Morley's description of this higher criticism is clearly derived from Arnold's "The Function of Criticism at the Present Time," as he labels it "genuine and wholly disinterested," standing "aloof from the agitation of the present," and helping to create "a literary atmosphere which is not choked with the acrid fumes of battle" (Morley, "Mr Pater's," 470, 471), this last phrase echoing Arnold's description of Cobbett as "blackened... with the smoke of a life-long conflict in the field of political practice" (Arnold, "Function of Criticism," 26). 
${ }^{75}$ Morley, “Mr. Pater's,” 471-472.

${ }^{76}$ Morley, “Mr. Pater’s,” 472.

${ }^{77}$ See, for example, Henry Morley's 1861 essay on Euphuism which sets up an opposition between ornate (Ruskinian) prose, and a proper communicative style, by pitting writing for "display" against a more "[d]irect, manly presentment...quietly told...with no paltry playing upon words, and no more stir of fancy or appeal to the emotions than arises naturally from the working of a mind intent upon its thought" (Henry Morley, "Euphuism," 382). For an extended discussion of debates about Ruskin's prose style in the 1860s see, Brian Maidment, "Readers Fair and Foul: John Ruskin and the Periodical Press," The Victorian Periodical Press: Samplings and Soundings ed. Joanne Shattock and Michael Wolff (Leicester: Leicester UP, 1982),29-58; and Jason Camlot, "Style and Victorian Criticism: John Ruskin's Political Economy of Literature," Signatures 3 (2001): 25-45.

${ }^{78}$ Morley, “Mr. Pater's,” 473.

${ }^{79}$ Morley, “Mr. Pater's,” 474.

${ }^{80}$ Cited in Lene Ostermark-Johansen, "The Death of Euphues: Euphuism and Decadence in Late-Victorian Literature," English Literature in Transition 45 (2002): 19 .

${ }^{81}$ Pater's conception of writing as the strategic rejection "of the facile, the otiose" and the elimination of all "surplusage" is derived in great part, not only from his reading of Flaubert, but from John Henry Newman's 1858 lecture entitled, 
"Literature," where the excellent writer is described as one who is "too serious to be otiose" and who "always has the right word for the right idea, and never a word too much" (John Henry Newman, "Literature," [1858] The Idea of a University, ed. Martin J. Svaglic [Notre Dame, Indiana: University of Notre Dame Press, 1986], 220). For an extended discussion of Newman's influence upon Pater's theory of style see David J. DeLaura, Hebrew and Hellene in Victorian England: Newman, Arnold, and Pater (Austin \& London: University of Texas Press, 1969), 329-338. DeLaura claims Newman as the primary source for Pater's ideas that matter and manner are inseparable, that writing is the representation of a specific personality, and for his stress upon "the artist's power of shaping and transforming language for his own special purposes" (335).

${ }^{82}$ Some examples of this view of Pater's mode of criticism from reviews of his work: William James Stillman suggests that Pater "is more interested in the perfection of his own style than in the mysteries of the art on which his studies are based," thus pitting style against scholarly responsibility (Stillman, "The Renaissance," Nation 17 [1873]: 243). Margaret Oliphant argues that Pater's criticism is based upon "the single word" that, worked up to mechanically, can move the reader to rapture, and is dismissed by this critic to be "as nearly pure nonsense as it is possible" (Oliphant, "The Old Saloon," Blackwood's Edinburgh Magazine 147 [1890]: 141). And C.L Graves remarks that Pater's writing is "not the work of a man of letters, but a 'stylist,'--to use a base coinage which has at 
least the merit of suggesting artificiality and affectation" (Graves, "Mr. Pater's Essays," Spectator 63 [1889]: 888).

${ }^{83}$ Walter Pater, Uncollected Essays (Folcroft, Pennsylvania: The Folcroft Press. Norwood Editions, 1976), 51.

${ }^{84}$ This review of Flaubert is often seen as the kernel of his expanded essay on style. See, for instance, Edmund Chandler, Pater on Style (Copenhagen:

Rosenkilde and Bagger, 1958), 9-11.

${ }^{85}$ This information on Pater's procedure of writing, and quotes from Gosse on Pater's act of composition are cited from, Gerald Monsman and Samuel Wright, "Walter Pater: Style and Text," South Atlantic Quarterly 71 (1972): 110-111. The extent of Pater's meticulous attention to the details of his prose in the form of revision is noted recently by Leve Ostermark-Johansen: "The impressive collation of the first (1885) and third (1892) edition of Marius, carried out by Edmund Chandler some forty years ago, established Pater's obsession with 'refinement' [i.e. revision]; no fewer than 6, 085 textual variations exist between the two editions, all of them minor ones such as punctuation and substitution of individual words. In most cases the syntax has been kept, Chandler observes, thus proving Pater's great attention to the individual word" (Ostermark-Johansen, 11).

${ }^{86}$ Cited in Monsman and Wright, 110.

${ }^{87}$ W.J. Courthope, "Appreciations," Nineteenth Century 27 (1890): 662. David Bromwich suggests that this "excess of sympathy" represents Pater's conscious replacement of Arnold's disinterestedness with a critical interestedness as the 
groundwork of culture. As Bromwich puts it, "Pater restores value to the personal and subjective impulses that animate even the effort to be disinterested." (David Bromwich, "The Genealogy of Disinterestedness," Raritan 1 [1982]: 77-78.) This does not mean, however, that Pater discards the possibility of an objective criticism outright. (Nor, do I think, does Arnold completely jettison the personal and subjective in his formulation of critical disinterestedness.) Rather, Pater attempts to correct overly simplistic conceptions of critical discourse by identifying the process of personal selection with critical veracity. Wolfgang Iser articulates this position succinctly when he remarks that Pater qualifies "the adequate translation of inwardness into language as truth." (Wolfgang Iser, Walter Pater: The Aesthetic Moment, trans. David Henry Wilson [Cambridge: Cambridge University Press, 1987], 49.)

${ }^{88}$ Again, T.S. Eliot's ideas of the individual talent's "process of depersonalization" (Eliot, 2173) and his dictum that "the emotion of art is impersonal" (2176) are usefully understood in Paterian terms.

${ }^{89}$ Wendell V. Harris, "Arnold, Pater. Wilde and the Object as in Themselves They See It," Studies in English Literature 11 (1971): 740.

${ }^{90}$ Iser, 45.

${ }^{91}$ Iser, 45.

${ }^{92}$ See Inman, 137-138.

${ }^{93}$ Pater, Renaissance, 99. 
${ }^{94}$ The source of this passage was first noted in Warwick Gould, "Pater's Mona Lisa and Flaubert's La Tentation de Saint Antoine," Notes and Queries 31 (1984): 500-1. Translations of passages from Flaubert's text in my essay are my own. The two passages, beginning with Pater's, run as follows: She is older than the rocks among which she sits; like the vampire, she has been dead many times, and learned the secrets of the grave; and has been a diver in deep seas, and keeps their fallen day about her; and trafficked for strange webs with eastern merchants; and, as Leda, was the mother of Helen of troy, and, as Saint Anne, the mother of Mary; and all of this has been to her but as the sound of lyres and flutes, and lives only in the delicacy with which it has moulded the changing lineaments, and tinged the eyelids and the hands. (Pater, The Renaissance, 99)

Elle a été L'Hélène des Troyens, dont le poète Strésichore a maudit la mémoire. Elle a été Lucrèce, la patricienne violée par les rios. Elle a été Dalila, qui coupait les cheveux de Samson. Elle a été cette fille d'Israël qui s'abbondonnait aux boucs. Elle a aimé l'adultère, l'idolâtrie, le mensonge et la sottise. Elle s'est prostituée à tous les peuples. Elle a chanté dans les carrefours. Elle a baisé tous les visages.

A Tyr, la Syrienne, elle était la maîtresse des voleurs. Elle buvait avec eux pendant les nuits, et elle cachait les assassins dans la vermine de son lit 
tiède. (Gustave Flaubert, La Tentation de saint Antoine [1874] [Paris:

Éditions Gallimard, 1983], 136)

${ }^{95}$ Brake, "Aesthetics in the Affray," 74.

${ }^{96}$ Cited in Denis Donoghue, Walter Pater: Lover of Strange Souls (New York:

Alfred A. Knopf, 1995), 79.

${ }^{97}$ Anderson, 116.

${ }^{98}$ Wilde, "Mr. Pater's Last Volume," [1890] The Artist as Critic, 230.

${ }^{99}$ Wilde, "The Soul of Man Under Socialism," [1891] The Artist as Critic, 275.

${ }^{100}$ For relevant works in the tradition of aesthetic psychology see Grant Allen's

Physiological Aesthetics (London: H.S. King, 1877); Francis Ysidro Edgeworth's

Mathematical Psychics (London: C.K. Paul, 1881); Emile Hannequin's La

Critique Scientific (n.p., 1888); and later Vernon Lee's The Handling of Words

(New York: John Lane, 1923). Among the earliest examples of scientific stylistics that I have found are the following: T.C. Mendenhall: "The Characteristic Curves of Composition." Science 9 (1887): 237-49, and "A Mechanical Solution to a Literary Problem." Popular Science Monthly 60 (1901): 97-105; Lucius Sherman: "Some Observations upon the Sentence-Length in English Prose" University Studies 1.2 (1888): 119-130, "On Certain Facts and Principles in the Development of Form in Literature" University Studies 1.4 (1892): 337-366, and The Analytics of Literature (Boston, 1893); G.W. Gerwig, "On the Decrease of Predication and of Sentence Weight in English Prose" University Studies 2.1 (1894): 17-44; and 
Edwin Herbert Lewis, The History of the English Paragraph (Chicago: U of Chicago P, 1894). 